\title{
Social Participation of Badoncek Culture for Maintaining Moral Education in Pariaman of Indonesia
}

\author{
F Annova ${ }^{1}$, A Darlis ${ }^{2}$, S Fitriani ${ }^{3}$ \\ Department of Islamic Education, Islamic College of Syekh Burhanuddin Pariaman, West \\ Sumatra, Indonesia ${ }^{1,3}$ \\ ${ }^{2}$ Department of Islamic Education, Islamic College of Jami'yah Mahmudiyah Tanjung Pura- \\ Langkat, North Sumatra, Indonesia ${ }^{2}$ \\ \{ fauzanaannova@gmail.com ${ }^{1}$, ahmaddarlisray@yahoo.co.id ${ }^{2}$, teticut-faria@yahoo.com $\left.{ }^{3}\right\}$
}

\begin{abstract}
The aim of this research was to analysis society in Pariaman for badoncek culture as social participation in maintaining moral education, as the nature and history social participation of badoncek culture, how do respons the society in Pariaman with the social participation of badoncek culture in maintaining moral education of society and how do badoncek culture in Islamic view cause all of humanity in Pariaman is Muslim. The population of this research all humanity in Pariaman of Indonesia simple random sampling technique was taken, 152 persons. This research was qualitative with a survey research type. Data were collected by using questionnaire and interview. The data analysis used descriptive statistical analysis and measuring the matriculation between agreeing and disagree on humanity with social participation of badoncek culture in maintaining moral education society in Pariaman of Indonesia. The result of this research showed that 1) The nature of social participation badoncek culture is giving donation at night after the wedding party. In this activity, all of the society and the relatives or relatives who have been invited by every family who holds the party will show their concern to participate in lightening the burden of them. 2) Respons the society in Pariaman showed that $91.4 \%$ of people, who agreed with badoncek culture in maintaining moral education and $8.6 \%$ who were disagreed by the reasons of them. 3) Islamic view for the badoncek, Islam is the religion of the rahmah lil alamin derived from the absolute truth (al-Quran and Hadith). Therefore, Islam considers that every good moral value must be the substance of the teachings of Islam itself. Furthermore, the most fundamental moral values in badoncek culture as described above are corporate (ta'awun), and share (shadaqah).
\end{abstract}

Keywords: Social Participation, Badoncek Culture, Moral Education. 


\section{Introduction}

Nowadays, quality of life is associated with indexes, which refer to the dimensions of health, education, environmental quality, economy, social scheme, social security, and social participation. Social Participation is one of the shapes the good interaction social[1]. Social Participation is one of the shapes the good interaction social.

Social Participation of Badoncek culture is one of the traditions or customs for the Pariaman community both in Pariaman in giving donation at night after the wedding party, for the help family who's got marriage. In this activity, the society and the relatives or relatives who have been invited by every family who holds party will show their concern to participate in lightening the burden of them.

Furthermore the value of cooperating, it is felt by Pariaman society at baralek, wedding party. Social participation of badoncek culture at night after baralek, very helpful to host in overcoming the debt baralek. Because of the custom of Pariaman people, when going to baralek they take all the groceries for cooking ingredients for baralek snacks in the Market, without paying first (indebted). Then the morning after badoncek, all debts are paid by those who have alek (people who held party). So there is nothing in Pariaman, a wedding without a party. The poor Pariaman people, during their children's marriage, will remain baralek as well. Because for the people it will be a big loss if baralek is no held. This is because on other occasions they will also be invited to badoncek on someone else's alek. Then badoncek culture as a form of caring fellow. Social Participation of badoncek culture also ever done Pariaman society, at the time of the fire house accident happened to a family or there is also a house that was destroyed by the fallen big tree collapsed.

Badoncek culture is an activity of fund raising for the common purpose in life of Pariaman society. Activity badoncek done if people need the money that will be used for the common good. Fundraising can be done for the purpose of construction of public facilities such as mosques, mushala, surau, youth office and so on. Social participation of Badoncek culture also seen during the marriage process of a woman which is called baralek. The principle of togetherness and kinship in badoncek culture is done voluntarily and openly, followed by people in kampong or in rantau. Donations are given in the form of money or material as needed. The size of the donation depends on the family relationship and the ability of each. Although it is open and tends to compete against each other, it is not perceived as riya or arrogant. At this time the broadcast culture increasingly widely used in meeting the needs of the community. Badoncek culture not only able to ease the burden but also, strengthen the sense of togetherness. Badoncek culture has developed in terms of utilization of this culture to the level of local government policy.

\section{Discussion}

\section{$2.1 \quad$ Related Work}

The badoncek culture was studied before by Syafwan Rozi. Focus this study was about the local wisdom and natural disaster in the West Sumatra. Community based disaster management is an attempt to optimeze the potential of social and local values in communities to facilitate the handling of natural disasters west sumatera as one of the disaster prone areas in Indonesia has a 
number of local wisdom values-a value combining religion and local culture - rooted in traditional philosophy; Adat Basandi Syara', Syara' Basandi Kitabullah”. The example of that local wisdom is customary ideas or proverbs in the form of legend and expressions, architectural design of the traditional house "Rumah Gadang", and the structure of the environment as well as the social systems of kinship and traditional administration in the form of Nagari. This research employed a qualitative method by using the ethnography approach.the data were collected through observation, participation in social events, an-in-depth interviews. Those techniques were applied to obtain the information and the meaning of events and behaviors comprehensively. The local values applied by the indigenous communities ah the victims of natural disasters in some regions of West Sumatra include "Badoncek" tradition in Nagari Tandikat Padang Pariman, the architecture of " Rumah Gadang” in Nagar Sungayang, Tanah Datar and disaster mitigation based on the district in Nagari Kubang Putih Agam [2].

My study in this article is especially about the social participation of badoncek culture in maintaining moral education in Pariaman of Indonesia. Focus the study about nature and history badoncek culture, respond the society to badoncek culture in maintaining moral education, and how do badoncek culture in the Islamic view.

\subsection{Materials and Method}

\subsubsection{Materials}

The material in this study was badoncek culture in Pariaman Minangkabau of Indonesia

\subsubsection{Method}

This study approach was qualitative and quantitative, conducted in the field directly in Priaman society. Research instruments to collect the data, as follow questionnaire, interview, and documentation. [3]. Analysis of the data in the form of simple statistical to describe in-depth the situation under study. It was taken from a questionnaire given to all society in Pariaman.

In the study, population is the target of the study is comprised of a number of people or anything that looks directly on the study conducted. Samples were taken by a simple random sampling technique with a total target of samples is 152 persons. The consideration of sampling is also based on the allocation of time.

Table 1: Characteristic of Respondents Based on Sex

\begin{tabular}{cc}
\hline Sex & Amount \\
\hline Male & 64 \\
\hline Female & 88 \\
\hline Total & 152 \\
\hline
\end{tabular}

From the table above for more detail can be seen from the grapic below:

Graphic 1: Characteristic of Respondents Based on Sex 


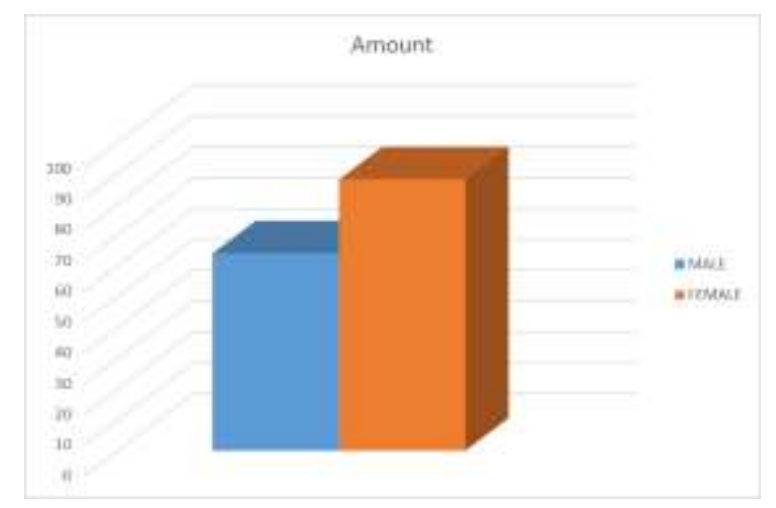

\subsubsection{Data Analysis Techniques}

The Questioner used for data analysis in order to see the total achievement of an item of respondents to answer the question via a questionnaire. The descriptive statistical analysis aims to look at the percentage achievement if respondent the answer of the questioner

$\mathrm{P}=\underline{\mathrm{f}} \times 100$

$\mathrm{N}$

Description :

$\mathrm{P}=$ Percentage

$\mathrm{f}=$ Frequency

$\mathrm{N}=$ the number

The interview was conductive that respond society was lived in Pariaman about social participation of badoncek culture fo maintaining moral education.

\section{$2.3 \quad$ Results}

\subsubsection{Analysis Natural And History of Badoncek Culture}

Social participation of Badoncek culture as one of the diversity of Minangkabau culture is very attached to Pariaman society of west Sumatera Indonesia, and its surroundings. Badoncek according to the story developed hereditary orally, it has existed since the time of its former. Social participation of badoncek culture is an activity of fundraising for the common purpose in the life of Pariaman society. Activity badoncek done if people need the money that will be used for the common good. Fundraising can be done for the purpose of the construction of public facilities such as mosques, mushala, surau, youth office and so on.

The technic of badoncek culture was spontaneous social participation in action and suitable for the needs of the moment. The society in Pariaman of Minangkabau in West Sumatra of Indonesia was spontaneously involved in the action initiated by local leaders with certain propaganda such us baralek (wedding party), construction mosque, or to help victims, etc. (interview, LKAM). 
Badoncek culture at its core has a deep meaning in the traditional Minangkabau philosophy. The essence of life shows that human beings do not live on their own, but they need to help each other and they should lend a hand to help social interest. Besides, badoncek not only socially sustains public activities, but it is more oriented to counter countries' limitations to overcoming public affairs, especially from the financial side. Badoncek culture was local wisdom has several advantages toward society's independence and the participation of the public [2].

The history of badoncek culture was "There used to be a man as bilal (garin) in a surau in one of the korong in Pariaman, the man was a descendant of a family who could not afford. He spent his days serving in the surau and also living in the surau. At that time there was a family wanted him to become a son-in-law or future husband to theirs. The news is known by one of his friends who both live in surau. His friend also convey the good news of the arrival of the female family to niniak mamak, urang tuo, urang kapalo mudo and urang sumando in the korong. After niniak mamak, urang tuo, kapalo mudo and urang sumando in the korong get the news then niniak mamak, urang tuo, urang kapalo mudo and urang sumando in the korong negotiate the intent and good intention of the family coming together in surau, and ask directly to the garin, whether he is willing to marry the daughter of the guest who has come.

Garin was willing to accept the good intent of the arrival of the guest, but then he said; "How can I marry his daughter, while my veryday life is only in surau? I do not have the expenses to hold my marriage ceremony with her daughter ". With the existence of such sentences from the garin, then niniak mamak, urang tuo, kapalo mudo and urang sumando in the korong and the local community held a deliberation to find a solution for marriage ceremony and the wedding could be implemented.

After discussed and found the solution is to hold badoncek / fundraising at night after the wedding so that the man can cover the entire cost of wedding and wedding ceremony. Seeing the kindness and background of the men's family then the community is very enthusiastic to help him, there is help with the energy to prepare the preparation of marriage, and some are with the material by holding badoncek (formerly called the badoncek to collect money in the wedding party nephew) of the people in the korong. Seeing the participation of the community then the male relatives (mamak, mandeh, apak, etek, brother and sister) and his friends also participate in badoncek so that all the costs of the implementation of the wedding can be fulfilled and even exceeds the capital of the implementation of the wedding. Formerly, the implementation of this badoncek if the capital of the wedding party has not been covered with a single round of badoncek then repeated badoncek until all the capital of the wedding party was covered. This round can be up to three times. Because once all the capital of the wedding party recorded on a book and must be issued in the event the badoncek. With the participation of the community and the relatives, the cost of the wedding for men is covered or fulfilled

According to its history, badoncek night s started because of the term "uang ilang" (lost money) and "uang japuik" (pickup money) provided by the family of the bride to the family of the bridegroom. As for the uang japuik and the uang ilang, its historical background was a wealthy family in the city of Pariaman worried, their adult girls are tread into an old maid, rich family in Pariaman City was taking an unusual way, by way of broadcasting from word of mouth happy, the family will spend some money, as the uang japuik and also the uang ilang to the prospective bridegroom / marapulai willing to marry his daughter. Uang japuik comes from a rich female dad. While the uang ilang to the prospective bridegroom came from mamak, relatives/kin of the rich family. Because of the responsibility of a mamak to his nephew. A 
mamak is responsible to find a husband candidate for his nephew, especially when a nephew is old enough and is suitable for marriage. Furthermore, mamak is also responsible for the wedding of his nephew. It is then developed and entrenched in society.(Interview, bundo kanduang kota Pariaman)

In the current development of uang japuik and uang ilang it is considered as a gift of living capital for married couple who married. So then this is considered as a positive culture by the Pariaman community, uang japuik, uang ilang, pasalaman and paragiah mintuo retained to this day. And badoncek as one of the solutions in the fulfillment adaik become an alternative that is considered very full of solution. According to history that mentioned, the authors concluded that badoncek backed by efforts to find a mate for girls, then experiencing development in the humanity and religiousness social, for the purpose of construction of public facilities such as mosques, mushala, surau, youth office and so on

\subsubsection{Badoncek Culture in Maintaining Moral Education of Society}

Results of the study reported the tabulation of data obtained by a frequency distribution table and describe the level of respons the socuety in Pariaman city that was taken from questionnaire that have been answered by respondents.

Table 2: Badoncek culture in maintaining moral education of society

\begin{tabular}{lcc}
\hline Category & Amount & Percentage \% \\
\hline Agree & 139 & $91,4 \%$ \\
\hline Disaggree & 13 & $8,6 \%$ \\
\hline Total & $\mathbf{1 5 2}$ & $\mathbf{1 0 0} \%$ \\
\hline
\end{tabular}

From the table above for more detail can be seen from the grapic below:

Graphic 1: Badoncek culture in maintaining moral education of society 


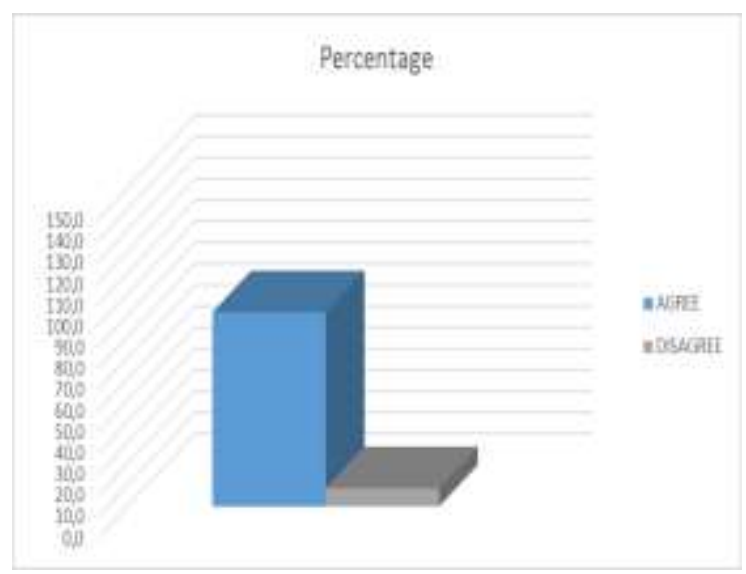

From these results based on maintaining moral education of the society by badoncek culture in Pariaman from 152 people $(91,4 \%)$, belong to the category of very good for maintaining moral education, and 13 of them $(8,6 \%)$ belong to the category disagree that badoncek culture in maintaining moral education.

The social participation of badoncek culture was very good in maintaining the moral education society in Pariaman of Indonesia. It can be concluded that social

participation of society in Pariaman of Indonesia in their social life has been included in the category of very good social participation in the moral education of society.

\subsubsection{Badoncek Culture in Islamic View}

The people of Pariaman and Padang Pariaman are Muslims. Almost all of the total population is Muslim, only a few are non-Muslims and they are migrants. The religious understanding of this society also influences the culture of badoncek. Related to badoncek activities that are still maintained by the community and even tend to develop to charity and social activities, sometimes colored by people's doubts might donate because of riya. Amid the spirit of donation or charity, there is also doubt whether or not to donate with the known of crowd.

In moral philosophical theory, there is a moral theory called moral absolutism, which looks that morality is eternal and will not change over time and place, the moral values are held by everyone and accepted by human ratio (Edwar Westermarck). The source of this idiocy comes from God, which must be realized in human life. It is a certainty that every group recognizes the existence of a god, must have absolute moral values, so that values are maintained all the time.

With regard to this, Islam is the religion of the rahmah lil alamin derived from the absolute truth (al-Quran and Hadith). Therefore, Islam considers that every good moral value must be the substance of the teachings of Islam itself. In the same way, the culture that has been described earlier, basically has the substance of positive moral values that are beneficial to human life, although the process of the activity is born from a thought of the outcome of human reason. 
Furthermore, the most fundamental moral values in badoncek culture as described above are cooporate (ta'awun), and share (shadaqah). Both moral values have been exemplified by the Prophet Muhammad as an example of Muslims. Explained that the nature of the Prophet's generosity in helping and doing good is faster than the wind that blows hard. As Jabir said "that the Messenger of Allah was never asked for anything then said no". Similarly the generosity and generosity of the apostle is totally unmatchable. In giving and helping others, the apostle is not afraid of the poor, as Ibn Abbas said "the Prophet is the most generous person in the month of Ramadan.

Cooperating (ta'awun) and sharing (shadaqah) in Islam are a virtue that must be done anytime and anywhere (absolute). The concept (ta'awun) is based on the absolute revelation of the Koran, including the Surah al-Maidah verse 2 below:

"And cooperate in righteousness and piety, but do not cooperate in sin and aggression. And fear Allah; indeed, Allah is severe in penalty".

Along with the verse, one day the Prophet Muhammad SAW once said:

"Abu Hurairah he said; The Messenger of Allah 'alaihi wasallam said:' Whoever frees a believer from a world of trouble, then Allah will free him from difficulty on the Day of Judgment. Whoever facilitates the person who is in trouble, then God will provide convenience in the world and in the hereafter. Whoever covers the disbelief of a Muslim, then God will cover his disgrace in the world and in the hereafter. Allah will always help His servant as long as the servant helps his fellow Muslims.[4]

The above verses and hadith, in general, emphasize that cooperate (ta'awun) based on the Shari'a is one of the Islamic teachings that must be practiced in this life. When the teachings can be realized properly, then the benefits will be created, the reward will be given by Allah as contained in the hadith.

In interpreting the above verse, al-Sya'rawi asserted that cooperate (ta'awun) is the thing that must be there to improve life. The repair of life itself requires a human who builds goodness and does not break the existing order of life.

Therefore, ta'awun works to build goodness instead of demolishing it, and the good is always in its goodness, to build a good life, demanding us to always cooporate (ta'awun) in kindness and taqwa. [5]

The concept of sharing (shadaqah) in Islam is described in many verses of the Qur'an, such as Al-Baqarah verse 3, Ar-Ra'du verse 22, and other verses. The point is, the Qur'an informs that sharing (shadaqah) in Islam is one of the most fundamental teachings. This is allegedly in Surah Ali Imran verse 92 below:

"Never will you attain the good [reward] untul you spend [in the way of Allah] from that which you love. And whatever you spend - indeed, Allah is Knowing of it".

In Islam, sharing (shadaqah) can be done in various forms and ways, in accordance with the wishes, and does not violate religious law. In this connection Allah SWT explains in the Quran surah al-Baqarah verse 271:

"If you disclose your charitable expenditures, they are good; but if you conceal them and give them to the poor, it is better for you, and He will remove from you some of your misdeeds [thereby]. And Allah, with what you do, is [fully] acquainted".

In Ibn Katsir's Tafsir it is explained that Allah SWT is great in order to fulfil promise. When someone inflicts some of his wealth in the way of Allah, in order to obtain His blessings, He will reward the better in the world and in the Hereafter. In the world he will get the blessing of 
sustenance, so Allah will always meet his needs. As for the hereafter Allah SWT will provide the heaven. This is the reply that the charitable person will not receive without sincerity. He is considered to have committed a tyranny and no one will help him when asked for accountability before Allah SWT (Abu al-Fida Ismail Ibn Umar Ibn Katsir al-Damsyiqi (w. 774 h))

In the next verse, Allah SWT asserted that the alms that are issued in a secret way are much more primary than the alms issued openly. Commenting on this verse, al-Mawardi asserted that there is no restriction in Islamic charitable giving (Ali ibn Muhammad al Mawardi). Furthermore he points out two opinions, namely; the first opinion of Ibn Abbas and Sufyan that says that the alms of al-Tathawwu 'is better (afdhal) to be kept as secret, because it is far more than the Riya nature, while obligatory alms (zakat) is better (afdhal) to be done openly, it is only to avoid suspicion the man/woman does not issue zakat. Secondly, the opinions of Yazid Ibn Abi Habib, al-Hasan and Qatadah who argue that charity, both alms and alms obligations, is better (afdhal) done in secret

It is understandable that charity can be done in two ways, namely by means of blatant and in vain ways. Both ways are closely related to someone's motivation to do so. It means that in any way someone suggests, which must be realized and emphasized is his intention to be due to God, not the other element.

Related to that, Rasulullah SAW said: "Reciting the Qur'an aloud like alms making open. Reciting the Quran is as slow as practicing alms in a closed way. "(HR Abu Dawud)

From the description above, it is asserting that there is a strong normative foundation for the substance of moral values in the development of the development of badoncek in Pariaman. Cooporating (Ta'awun) and sharing (shadaqah) in the activities of the badoncek are positive moral value that has a positive justification in the teachings of Islam. As regards the technical charitable giving of the assistance done in this activity, not being separated from two ways allowed in Islam. Islam allows for charity in a blatant way. It is openly allowed by Allah SWT, as long as it is not riya, though it is not among the more important. Riya and sincere things, this is the affair of the people who give alms to their Lord. No one has the right to judge someone else or not. If it shows alms given, then it is good deeds. If hiding alms and giving it to the needy, then hiding the charity is better done because of the act away from riya. [6]

When it comes down to encouraging the possessions in the possessions, the Companions ask the Prophet directly whether the charity is in secret or overtly? Then Allah sent the above verse to answer at once allowing charity in two ways. (Mahmud Ibn Abdillah al-Alusi). In Islam, the consequences of a riya are very fatal. The Messenger of Allah once informed that there were three groups who were first commanded to feel the fire of hell, ie the readers of the Qur'an (qari), warriors (mujahid) and people who give charity. They do it to say "fulan is qari, fulan is brave, fulan is the giver", whose deeds are not sincere for God[7]

In order to maintain (in anticipation) so that the charitable activities remain in the corridors of religious law, it is necessary to give intense understanding to the community, carefully guard the heart, not to slip when contributing to the badoncek activity.

\section{Conclussion}

Based of the result of this research, showed that, the nature of social participation badoncek culture is giving donation at night after wedding party. In this activity all of the society and the relatives or relatives who have been invited by every family who hold party will show their 
concern to participate in lightening the burden of them. Than, respons the society in Pariaman showed that $91.4 \%$ people, who were agree with badoncek culture in maintaining moral education and $8.6 \%$ who were disagree by the reasons of them. Badoncek culture in Islamic view was a good culture. Therefore, Islam considers that every good moral value, must be the substance of the teachings of Islam itself. Furthermore, the most fundamental moral values in badoncek culture as described above are cooporate (ta'awun), and share(shadaqah). So, based this reseach, we know that participation social of badoncek culture can to maintaing=ing moral education of the society. Respon social the society will be better wiyh the badoncek culture..

\section{References}

[1] H. Lune and B. L. Berg, Qualitative research methods for the social sciences. Chicago: Pearson Higher Ed, 2016.

[2] S. Rozi, "Local Wisdom and Natural Disaster in West Sumatra," El Harakah, vol. 19, no. 1, p. 1, 2017.

[3] J. H. McMillan and S. Schumacher, Research in education: A conceptual introduction. Little, Brown, 1984.

[4] M. I. H. Al-Naisaburi, Shahīh Muslim. Kairo: Dar al-Fikr, 1981.

[5] Al-Sya'rawi, Muhammmad Mutawalli, Tafsir al-Sya'rawi. Dār Akhbār al-Yaum, 1991.

[6] M. A. As-Shabuni, Tafsir-tafsir Pilihan. Jakarta: Pustaka Al-Kautsar, 2001.

[7] I. Q. Al-Jauziyah, Pendakian Menuju Allah. Jakarta: Pustaka Al-Kautsar, 1989. 